\title{
Estimating milk yield and value losses from increased somatic cell count on US dairy farms
}

\author{
J. C. Hadrich, ${ }^{* 1}$ C. A. Wolf, $†$ J. Lombard, $\ddagger$ and T. M. Dolak§ \\ *Department of Applied Economics, University of Minnesota, St. Paul 55108 \\ †Department of Agricultural, Food, and Resource Economics, Michigan State University, East Lansing 48824 \\ fUSDA, Animal and Plant Health Inspection Service, Veterinary Services, Fort Collins, CO 80526 \\ §Department of Agricultural and Resource Economics, Colorado State University, Fort Collins 80523
}

\begin{abstract}
Milk loss due to increased somatic cell counts (SCC) results in economic losses for dairy producers. This research uses 10 mo of consecutive dairy herd improvement data from 2013 and 2014 to estimate milk yield loss using SCC as a proxy for clinical and subclinical mastitis. A fixed effects regression was used to examine factors that affected milk yield while controlling for herd-level management. Breed, milking frequency, days in milk, seasonality, SCC, cumulative months with SCC greater than 100,000 cells/mL, lactation, and herd size were variables included in the regression analysis. The cumulative months with SCC above a threshold was included as a proxy for chronic mastitis. Milk yield loss increased as the number of test days with SCC $\geq 100,000$ cells $/ \mathrm{mL}$ increased. Results from the regression were used to estimate a monetary value of milk loss related to SCC as a function of cow and operation related explanatory variables for a representative dairy cow. The largest losses occurred from increased cumulative test days with a SCC $\geq 100,000$ cells $/ \mathrm{mL}$, with daily losses of $\$ 1.20 /$ cow per day in the first month to $\$ 2.06 /$ cow per day in mo 10 . Results demonstrate the importance of including the duration of months above a threshold SCC when estimating milk yield losses. Cows with chronic mastitis, measured by increased consecutive test days with $\mathrm{SCC} \geq 100,000$ cells $/ \mathrm{mL}$, resulted in higher milk losses than cows with a new infection. This provides farm managers with a method to evaluate the trade-off between treatment and culling decisions as it relates to mastitis control and early detection.
\end{abstract}

Key words: mastitis, economics, SCC, milk yield

Received September 14, 2017.

Accepted November 25, 2017.

${ }^{1}$ Corresponding author: jhadrich@umn.edu

\section{INTRODUCTION}

Mastitis is one of the most expensive sources of disease costs on dairy farms (DeGraves and Fetrow, 1993; Seegers et al., 2003; Hand et al., 2012; Geary et al., 2012). Previous survey work has found the incidence of mastitis in US dairy herds rising over time (USDANAHMS, 2016), whereas milk quality premium standards have become more rigorous over the same time period. These factors have created a situation where mastitis cost and control measures are increasingly important to farm financial viability.

Somatic cell count is frequently used as a proxy for mastitis. Past research has evaluated the relationship between mastitis and milk yield loss. Hand et al. (2012) studied the relationship between 24 -h milk loss and lactation milk loss due to mastitis across multiple herds to find milk loss increased across parity and production levels. Houben et al. (1993) emphasized a production loss bias due to dairy farmers likely keeping high-producing cows with mastitis but removing low-producing cows with mastitis. Other studies have focused on determining test-day milk yield loss at a cow level and found that parity, SCC, and herd-level management affects the amount of milk yield loss estimated (Jones et al., 1984; Bartlett et al., 1990; Lescourret and Coulon, 1994; Hortet et al., 1999; Miller et al., 2004; Durr et al., 2008). Comprehensive meta-analysis concluded that the economic cost of mastitis was a function of decreased milk yield, increased veterinary, labor, and treatment costs, reduced milk production, and premium payments received, among other factors (Houben et al., 1993, Seegers et al., 2003; Hand et al., 2012). Rollin et al. (2015) used a deterministic partial budget to estimate the economic impact of clinical mastitis in the first 30 $\mathrm{d}$ of the lactation to find that estimated future milk production losses resulted in $28 \%$ of the total cost of mastitis. Many of these studies focus on evaluating the relationship in a controlled experimental setting with a small number of cows, whereas other studies have used a repeated sample of dairy cows to estimate the 
relationship between milk yield loss and SCC (Barkema et al., 1999; Hortet et al., 1999; Bar et al., 2007; Hand et al., 2012).

Our analysis uses a large sample of DHI records from US dairy farms over 10 consecutive monthly test days. As DHI records do not routinely capture producer-identified mastitis events, we were not able to determine which cows were diagnosed or treated for mastitis. Instead, a threshold SCC was used as a proxy for mastitis for this analysis. Chronic mastitis was captured with the number of cumulative test days above the threshold SCC. Milk yields were estimated using a fixed effect regression analysis to provide an estimate of the indirect losses associated with SCC controlling for herd-level effects. These results are used to estimate the value of milk losses related to SCC as a function of cow- and operation-related explanatory variables. Our study contributes to previous research in 2 ways. First, this model evaluates the joint effect of numerous characteristics on milk quantity. This allows an examination of how factors change milk quantity while holding all other values constant. It also creates an opportunity to evaluate whether potential interactions exist across variables. Second, this analysis uses a large national sample of dairy cows with 10 mo of consecutive test-day lactation data.

\section{MATERIALS AND METHODS}

\section{DHIA Data}

Data from 2013 to 2014 DHI records were provided by AgriTech Analytics (Visalia, CA), AgSource Cooperative Services (Verona, WI), and Dairy Records Management Systems (DRMS; Raleigh, NC) via data transfer agreements with Colorado State University. These records included information on the cow, herd, and test-day (TD) milk yield, protein, and fat levels, and SCS in addition to cow, herd, and regional characteristics. A 10-mo balanced panel was generated from cows with consecutive TD of milk yield and SCC data beginning with the first TD of the lactation for each cow. The period covered included records from October 2013 through December 2014. A unique identifier was generated for each cow, which connected all cows within 1 herd. This allowed for a comprehensive analysis that tracked cows over identical time periods controlling for unobservable management differences within a herd. Cows with missing values for any of the variables used in the regression were dropped from the data set. This resulted in a data set with 5,415,940 individual cow lactation observations from 541,594 cows across 11,740 farms with 10 mo of TD data.

\section{Variable Definitions}

The data contained many cow and herd characteristics used to explain milk production levels in regression models. The variables used are explained here with a focus on the role of SCC on milk yield. The dependent variable in all regressions was TD milk yield per cow. The data also contained information on butterfat and protein yields. Past research suggested that SCC did not have an economically significant effect on milk component levels (Hortet and Seegers, 1998; Seegers et al., 2003). We estimated fat and protein components as dependent variables in the regressions and found results consistent with past research; therefore, it has been excluded from this paper.

To examine whether the explanatory variables had systematic relationships based on cow productivity, milk yield level was controlled by classifying cows into 3 production groups: low, medium, or high. The production groups were defined based on the distribution of cow-level data. The lowest $25 \%$ of the cows annually produced less than $9,072 \mathrm{~kg}$ of milk over $305 \mathrm{~d}$ and were classified as the low-production group. The highest $25 \%$ of cows produced greater than $12,700 \mathrm{~kg}$ of milk over $305 \mathrm{~d}$ and were classified as the high-production group. Cows that produced between 9,072 and $12,700 \mathrm{~kg}$ of milk in $305 \mathrm{~d}$ were classified as the medium-production group. Based on this cow-level categorization, it is possible that 1 herd could have cows in all 3 production groups.

Explanatory variables, other than season, were either cow- or herd-specific. Herd-level factors were assumed to apply to all cows in a herd. Cow-specific variables included breed, DIM, and lactation. Herd variables included milking frequency and herd size.

Previous literature has demonstrated that milk yield is influenced by the breed of the cow (Prendiville et al., 2009; Kadri et al., 2015). Multiple breeds and breed combinations were reported in the DHI data. Our analysis used the top 3 cow breeds reported, Holstein, Jersey, and crossbred, to evaluate its effect on milk yield loss. Holstein was set equal to 1 for all Holsteins and 0 otherwise. A similar variable was created for Jersey and crossbred.

As dairy farms have become larger and more specialized, the adoption of increased milking frequency has occurred on many operations (Erdman and Varner, 1995). DHI records allowed for 2 options for milking frequency: $2 \times$ or $3 \times$ a day. The majority of herds reported $2 \times$ milking frequency (MFQ); MFQ was set equal to 1 if the cow was milked $2 \times$ daily and 0 if the cow was milked $3 \times$ per day (MFQ did not change across the 10-mo lactation for an individual cow). 
A dummy variable for the test day, $\mathrm{TD}_{\mathrm{t}}$, was included for each cow and test day, t. The 10 dummy variables provide an identifier for the month within a 305-d lactation, as well as an additional measure to evaluate how milk yield changes across the 10-mo lactation. Days in milk on test day t, $\mathrm{DIM}_{\mathrm{t}}$, was used to capture the lactation length between test days throughout the study period as well as the linear lactation effect. Traditionally, lactation curves have a quadratic effect, which was included in the analysis by squaring DIM $_{t}$ to generate DIMSQ $_{\mathrm{t}}$. Season was incorporated in the analysis as dummy variables and defined as spring (March April, May), summer (June, July, and August), fall (September, October, November), and winter (December, January, February).

Somatic cell counts were used as a proxy for mastitis for each test day reported, SCCTD. The continuous SCC value reported within the DHI records were used for AgriTech and AgSource; DRMS reported a linear score that was converted to continuous milk SCC in cells per milliliter (Norman et al., 2016; $\mathrm{SCC}=2^{\text {(SCS -3) }}$ $\times$ 100,000). Hortet et al. (1999) and Hand et al. (2012) found that SCC $>100,000$ cells $/ \mathrm{mL}$ were a potential indicator of mastitis. As the number of months with a SCC $>100,000$ cells $/ \mathrm{mL}$ increases, milk losses associated were expected to increase. Additionally, a variable was created to account for the cumulative number of times the reported test day SCC was greater than or equal to $100,000,200,000$, or 300,000 cells $/ \mathrm{mL}$. This variable was used to identify the cumulative effect of persistently higher SCC levels as a proxy for chronic mastitis within a lactation.

Milk loss due to mastitis has been shown to be affected by the lactation of the cow. Cited milk yield losses in the first lactation ranged from 65 to $247 \mathrm{~kg}$ and 117 to $348 \mathrm{~kg}$ in subsequent lactations (Ostergaard and Grohn, 1999; Swinkels et al., 2005; Bar et al., 2008). Two lactation dummy variables, coded 0 or 1 , were included to capture first and second or more lactations for the individual cow.

Herd size was also reported in the DHI records. Herd size is a proxy for many factors, including technology, facilities, diet, and unobserved herd-level management. Four herd sizes were used to capture size effects: 1 to 99, 100 to 499,500 to 999 , and 1,000 or more milk cows in the herd.

\section{Fixed Effect Regression Analysis}

A fixed effect regression was used to estimate milk production over 10 mo of TD for each cow with the fixed effect at herd level. Fixed effect regressions use a data set that includes repeated observations on the same cross section (cow) over time (Wooldridge, 2002) to estimate the effects of time-varying explanatory variables. This allows for arbitrary correlation between the additive unobserved heterogeneity, herd management (herd-level fixed effect), and the explanatory variables. A fixed effect regression allows the researcher to follow the cow over time to determine which factors may cause a decrease in milk quantity while jointly controlling for unobserved management characteristics captured at the herd or farm level. The fixed effects model takes the form

$$
\begin{aligned}
& Y_{j t}=\beta_{0}+\beta_{1} \text { Holstein }_{j t}+\beta_{2} \text { Jersey }_{j t}+\beta_{3} \text { Crossbred }_{j t}+ \\
& \beta_{4} M F Q_{j t}+\beta_{5} D I M_{j t}+\beta_{6} D I M S Q_{j t}+\beta_{7} \text { spring }_{j t}+ \\
& \beta_{8} \text { summer }_{j t}+\beta_{9} \text { fall }_{j t}+\beta_{10} \text { winter }_{j t}+\sum_{k=11}^{20} \sum_{i=1}^{10} \beta_{k} T D_{i}+ \\
& \beta_{21} S C C_{j t}+\beta_{22} S C C_{-} 100_{j t}+\beta_{23} \text { Lactation }_{j t}+
\end{aligned}
$$

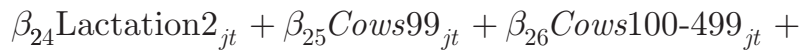

$$
\begin{aligned}
& \beta_{27} \text { Cows500-999 } 9_{j t}+\beta_{28} \text { Cows } 1,000_{j t}+\left(c_{j}+u_{j t}\right) \text {, }
\end{aligned}
$$

where $Y_{j t}$ is the milk yield for cow $j$ on test day $t, t=1$, $\ldots, 10 ; \beta_{0}$ is the intercept; $\beta_{1} \ldots \beta_{28}$ are estimated coefficients for the set of explanatory variables, $X_{j t}$, that may influence milk yield; $c_{j}$ is the unobserved heterogeneity; and $u_{j t}$ is the error term; $k$ is the subscript for the beta coefficients estimated for $\mathrm{TD} i$. This specification assumes the error term is uncorrelated with the explanatory variables across all time periods while allowing for arbitrary correlation between the unobserved heterogeneity (herd fixed effect) and the explanatory variables (Wooldridge, 2002).

Use of dummy or binary variables requires that 1 category be dropped to avoid the dummy variable trap. The base category that was dropped in these regressions included Holstein, spring, TD1, lactation 1, milked 3× a day, and in a herd with 99 cows or less. The estimates of categorical variables should be interpreted as difference from these omitted categories.

\section{Valuing Milk Losses}

To clarify appropriate interpretation of results, average US milk price during 2014 and 2015 of $\$ 0.45 / \mathrm{kg}$ (\$20.54/cwt; USDA-NASS, 2016) was used along with typical cow characteristics to examine the monetary value of milk losses over a lactation. An example cow is used to illustrate the effects of herd and animal characteristics by multiplying the milk yield coefficient by the milk price. 
Table 1. Variables and summary statistics, mean, and share values

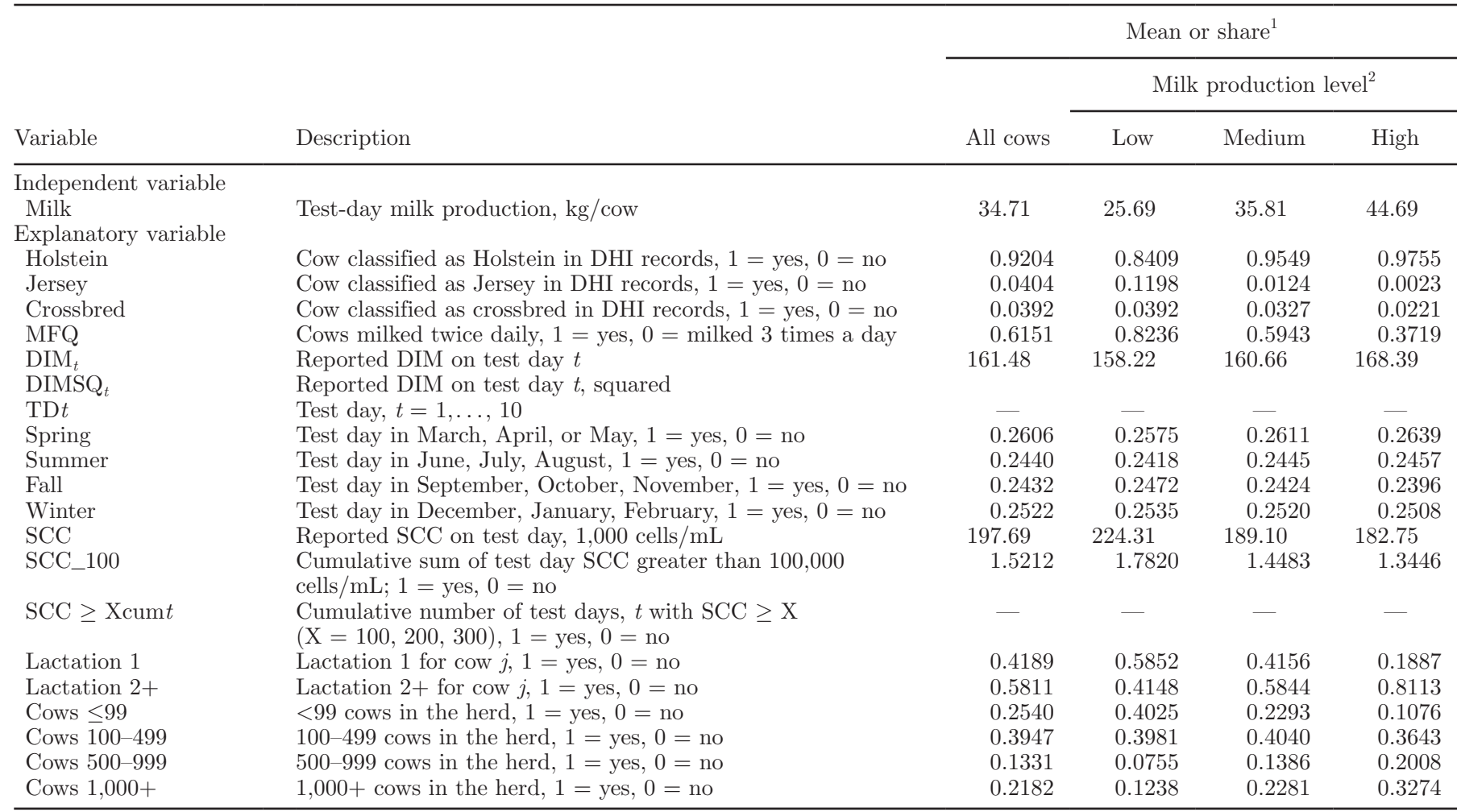

${ }^{1}$ Binary summary statistics reported indicate the share reported in each category while the mean value is reported for continuous variables.

${ }^{2}$ Low production was $<9,700 \mathrm{~kg} /$ cow, medium production was $9,700-12,700 \mathrm{~kg} /$ cow, high production was $>12,700 \mathrm{~kg} / \mathrm{cow}$.

\section{RESULTS AND DISCUSSION}

\section{Summary Statistics}

The average TD milk production across all cows was $34.71 \mathrm{~kg} /$ cow (Table 1). Ninety-two percent of the cows in the data set were Holstein, 4\% Jersey, and the remaining $4 \%$ were categorized as crossbred. Twice daily milking was used on approximately $62 \%$ of the cows, whereas the remaining $38 \%$ were milked $3 \times$ a day. The lactation cycle included in this analysis follows 10 consecutive months of data, whereas seasons were included across the 12 mo of the year. The average SCC across all cows was 197,690 cells/mL, with the average cow having 1.5 consecutive months above a SCC of 100,000 cells $/ \mathrm{mL}$. Forty-two percent of all cows were in their first lactation, with the remaining $58 \%$ in their second or greater lactation. The majority of the cows were in a herd with less than 500 cows $(65 \%)$. About $22 \%$ of the cows were in herds with more than 1,000 cows.

Table 1 also displays summary statistics by milk production level. The low-producing cows were milked twice a day at a higher rate than the high-producing cows. Low-producing cows also had higher SCC. High- producing cows were more often Holstein, in second or higher lactation, and part of large herds.

\section{Regression Results}

A fixed effect regression was estimated using Stata (StataCorp, 2015) on a 10-mo repeated sample of 541,594 dairy cows across 11,740 US dairy farms. The regression estimated milk yield as a function of explanatory variables. The coefficients should be interpreted as the marginal effect of that variable at the mean in terms of kilograms of milk per day, all other factors held constant. In the case of dummy or binary variables, the coefficient is the difference between when that variable applied (coded as 1) and when it did not (coded as 0). For each set of those variables, a base scenario was omitted. The base scenario in the regressions below was a Holstein cow on TD1 in her first lactation milked $3 \times$ a day in a herd with less than 99 cows during the spring.

Four sets of regression results are presented in Table 2. The first estimate reported in column 1 includes all cows, regardless of production level. The 3 remaining columns of regression output estimates are by produc- 
Table 2. Estimated test-day milk yield coefficients $(\mathrm{kg} / \mathrm{d})$ by production level ${ }^{1}$

\begin{tabular}{|c|c|c|c|c|}
\hline \multirow[b]{2}{*}{ Item } & \multirow[b]{2}{*}{ All cows } & \multicolumn{3}{|c|}{ Milk production level $^{2}$} \\
\hline & & Low & Medium & High \\
\hline Constant & $35.0728^{* *}$ & $30.6209^{* *}$ & $32.8012^{* *}$ & $45.3762^{* *}$ \\
\hline Jersey & $-9.6848^{* *}$ & $-4.7408^{* *}$ & $-12.2068^{* *}$ & $-14.0106 \dagger$ \\
\hline Crossbred & $-6.2574^{* *}$ & $-6.2673^{* *}$ & $-4.6294^{* *}$ & $-14.5753^{* *}$ \\
\hline MFQ & $-2.2553^{* *}$ & $-0.8233 \dagger$ & $-1.6131^{* *}$ & $-6.1355^{* *}$ \\
\hline DIM & $0.0151^{* *}$ & $-0.0051^{* *}$ & $0.0134^{* *}$ & 0.0018 \\
\hline DIMSQ & $-0.0001^{* *}$ & $0.0000^{* *}$ & $-0.0001^{* *}$ & $0.0000^{* *}$ \\
\hline Summer & $-0.8533^{* *}$ & $-0.5721^{* *}$ & $-0.8059^{* *}$ & $-1.1155^{* *}$ \\
\hline Fall & $-1.6189^{* *}$ & $-1.2561^{* *}$ & $-1.5400^{* *}$ & $-2.0182^{* *}$ \\
\hline Winter & $-0.5522^{* *}$ & $-0.4218^{* *}$ & $-0.5164^{* *}$ & $-0.7376^{* *}$ \\
\hline TD2 & $5.0728^{* *}$ & $3.7156^{* *}$ & $5.4345^{* *}$ & $7.3168^{* *}$ \\
\hline TD3 & $4.8148^{* *}$ & $3.7470^{* *}$ & $5.2999^{* *}$ & $7.3391^{* *}$ \\
\hline TD4 & $3.8622^{* *}$ & $3.3657^{* *}$ & $4.3966^{* *}$ & $6.2352^{* *}$ \\
\hline TD5 & $2.8580^{* *}$ & $3.0246^{* *}$ & $3.4081^{* *}$ & $4.8039^{* *}$ \\
\hline TD6 & $1.9358^{* *}$ & $2.8015^{* *}$ & $2.4496^{* *}$ & $3.3167^{* *}$ \\
\hline TD7 & $1.0769^{* *}$ & $2.6749^{* *}$ & $1.5186^{* *}$ & $1.7086^{* *}$ \\
\hline TD8 & $0.2195^{*}$ & $2.5622^{* *}$ & $0.5670^{* *}$ & -0.0882 \\
\hline TD9 & $-0.8295^{* *}$ & $2.3080^{* *}$ & $-0.6003^{* *}$ & $-2.3213^{* *}$ \\
\hline TD10 & $-2.4904^{* *}$ & $1.6091^{* *}$ & $-2.4215^{* *}$ & $-5.5278^{* *}$ \\
\hline $\mathrm{SCC}$ & $-0.0013^{* *}$ & $-0.0010^{* *}$ & $-0.0014^{* *}$ & $-0.0016^{* *}$ \\
\hline SCC_100 & $-0.5323^{* *}$ & $-0.5047^{* *}$ & $-0.6172^{* *}$ & $-0.4791^{* *}$ \\
\hline Lactation $2+$ & $1.0857^{* *}$ & -0.0888 & $0.6639^{*}$ & $4.7941^{* *}$ \\
\hline Cows 100-499 & 0.0285 & $-4.2807^{* *}$ & 2.5082 & 0.4864 \\
\hline Cows 500-999 & $2.3448^{*}$ & -2.0328 & $8.0519^{* *}$ & -5.7543 \\
\hline Cows $1,000+$ & $4.8114^{* *}$ & 0.4893 & $7.8446^{*}$ & -2.1905 \\
\hline $\mathrm{R}^{2}$ & 0.3261 & 0.2941 & 0.3307 & 0.3833 \\
\hline Cow observations & $5,415,940$ & $1,509,977$ & $2,857,645$ & $1,048,318$ \\
\hline
\end{tabular}

tion level (low, medium, high; production level regressions were found to be statistically different from the "all cows" regression). This was completed to compare coefficients across production groups to determine if different explanatory variables affected milk yield. For example, from the first column, a cow milked $2 \times$ daily produced $2.26 \mathrm{~kg} / \mathrm{d}$ less than a cow milked $3 \times$ daily with all other factors (e.g., herd size, test day, DIM, lactation) held constant. This estimate can be added to the constant in the first column, $36.04 \mathrm{~kg} / \mathrm{TD}$, to result in an updated milk yield of $33.78 \mathrm{~kg} / \mathrm{TD}$ with other factors constant. This process could be repeated to evaluate the effect of various explanatory variables on milk production for the base scenario.

Breed affects milk quantity and quality (Prendiville et al., 2009; Kadri et al., 2015). Jersey and crossbred cows were found to have lower milk yield compared with Holstein cows, but had higher components to make up for the lower quantity (which were not analyzed in this regression). Milking frequency affects overall milk yield. These results showed that, as expected, cows milked twice daily produced on average less than cows milked $3 \times$ daily. Whereas DIM and DIMSQ have small estimated effects, they are included in the analysis with the
TD dummy variables to represent the typical lactation curve shape. Milk yield is also affected by the month in which the cow is producing. Referring to Table 2 , a cow in the second month of her lactation (TD2) had 5.07 $\mathrm{kg} / \mathrm{TD}$ more milk than on her first test day. This value decreased each subsequent month, until TD9, when the average cow produced less than what she did on her first test day. Season was also found to affect milk yield, with all seasons having lower milk yield compared with spring months. Cows in their second or greater lactation were found to produce, on average, $1.09 \mathrm{~kg} / \mathrm{TD}$ more than their first-lactation counterparts controlling for all other effects included in the model.

Cow-level milk production and producer-level management decisions are joint factors. For example, if a low-producing cow continues to be mastitic, a farmer may be more willing to sell that cow compared with a high-producing cow (Houben et al., 1993; Smith et al., 2000; Bar et al., 2007, 2008). This section discusses results across the 3 production groups (last 3 columns of Table 2). With respect to milk production levels, the results follow a similar pattern with some interesting exceptions. The low-producing cows had lactation curves with lower peak milk production than the me- 
Table 3. Proportion of observations with cumulative days of SCC greater than 100,000, 200,000, and 300,000 cells $/ \mathrm{mL}$

\begin{tabular}{lccc}
\hline & \multicolumn{3}{c}{ Test-day SCC threshold } \\
\cline { 2 - 4 } Item $^{1}$ & $\geq 100,000$ & $\geq 200,000$ & $\geq 300,000$ \\
\hline SCC $\geq$ Xcum1 & 0.2315 & 0.1888 & 0.1643 \\
SCC $\geq$ Xcum2 & 0.1043 & 0.0703 & 0.0566 \\
SCC $\geq$ Xcum3 & 0.0630 & 0.0392 & 0.0308 \\
SCC $\geq$ Xcum4 & 0.0441 & 0.0261 & 0.0198 \\
SCC $\geq$ Xcum5 & 0.0329 & 0.0184 & 0.0135 \\
SCC $\geq$ Xcum6 & 0.0251 & 0.0132 & 0.0093 \\
SCC $\geq$ Xcum7 & 0.0192 & 0.0095 & 0.0065 \\
SCC $\geq$ Xcum8 & 0.0145 & 0.0066 & 0.0042 \\
SCC $\geq$ Xcum9 & 0.0102 & 0.0020 & 0.0025 \\
SCC $\geq$ Xcum10 & 0.0058 & 0.0011 \\
No. of observations & 0.55 & 0.38 & 0.0018 \\
Proportion of all observations & $2,983,852$ & $1,671,881$ \\
\hline
\end{tabular}

${ }^{1} \mathrm{Xcumt}=$ cumulative number of test days, $\mathrm{t}$, with $\mathrm{SCC} \geq \mathrm{X}(\mathrm{X}=100,200$, or 300$)$.

Table 4. Estimated test-day milk yield coefficients $(\mathrm{kg} / \mathrm{d})$ by cumulative SCC thresholds ${ }^{1}$

\begin{tabular}{|c|c|c|c|}
\hline \multirow[b]{2}{*}{ Item } & \multicolumn{3}{|c|}{ Test-day SCC threshold } \\
\hline & $\geq 100,000$ & $\geq 200,000$ & $\geq 300,000$ \\
\hline Constant & $35.5969^{* *}$ & $35.3532^{* *}$ & $35.2413^{* *}$ \\
\hline Jersey & $-9.9898^{* *}$ & $-9.8928^{* *}$ & $-9.8913^{* *}$ \\
\hline Crossbred & $-5.9822^{* *}$ & $-6.4625^{* *}$ & $-6.5094^{* *}$ \\
\hline MFQ & $-2.2282^{* *}$ & $-2.2614 \dagger$ & $-2.2682^{* *}$ \\
\hline DIM & $0.0112^{* *}$ & $0.0133^{* *}$ & $0.0141^{* *}$ \\
\hline DIMSQ & $-0.0001^{* *}$ & $-0.0001^{* *}$ & $-0.0001^{* *}$ \\
\hline Summer & $-0.8050^{* *}$ & $-0.8078^{* *}$ & $-0.8168^{* *}$ \\
\hline Fall & $-1.6084^{* *}$ & $-1.6056^{* *}$ & $-1.6101^{* *}$ \\
\hline Winter & $-0.5714^{* *}$ & $-0.5617^{* *}$ & $-0.5585^{* *}$ \\
\hline TD2 & $4.4785^{* *}$ & $4.7245^{* *}$ & $4.7934^{* *}$ \\
\hline TD3 & $4.2015^{* *}$ & $4.4173^{* *}$ & $4.4687^{* *}$ \\
\hline TD4 & $3.2682^{* *}$ & $3.4343^{* *}$ & $3.4640^{* *}$ \\
\hline TD5 & $2.2657^{* *}$ & $2.3937^{* *}$ & $2.4076^{* *}$ \\
\hline TD6 & $1.3374^{* *}$ & $1.4199^{* *}$ & $1.4225^{* *}$ \\
\hline TD7 & $0.4865^{* *}$ & $0.5028^{* *}$ & $0.4892^{* *}$ \\
\hline TD8 & $-0.3189^{* *}$ & $-0.4080^{* *}$ & $-0.4437^{* *}$ \\
\hline TD9 & $-1.2233^{* *}$ & $-1.4846^{* *}$ & $-1.5632^{* *}$ \\
\hline TD10 & $-2.3992^{* *}$ & $-2.9606^{* *}$ & $-3.1550^{* *}$ \\
\hline SCC & $-0.0009^{* *}$ & $-0.0009^{* *}$ & $-0.0010^{* *}$ \\
\hline $\mathrm{SCC}>\mathrm{Xcum} 1$ & $-2.6623^{* *}$ & $-1.9483^{* *}$ & $-1.5745^{* *}$ \\
\hline $\mathrm{SCC} \geq \mathrm{Xcum} 2$ & $-1.2157^{* *}$ & $-0.5924^{* *}$ & $-0.2390^{* *}$ \\
\hline $\mathrm{SCC} \geq \mathrm{Xcum} 3$ & $-1.2464^{* *}$ & $-0.7323^{* *}$ & $-0.4091^{* *}$ \\
\hline $\mathrm{SCC} \geq \mathrm{Xcum} 4$ & $-1.4666^{* *}$ & $-1.0295^{* *}$ & $-0.7202^{* *}$ \\
\hline $\mathrm{SCC} \geq \mathrm{Xcum} 5$ & $-1.6731^{* *}$ & $-1.3277^{* *}$ & $-1.0448^{* *}$ \\
\hline $\mathrm{SCC}>\mathrm{Xcum} 6$ & $-1.8927^{* *}$ & $-1.5621^{* *}$ & $-1.2989^{* *}$ \\
\hline $\mathrm{SCC} \geq \mathrm{Xcum} 7$ & $-2.1815^{* *}$ & $-1.8021^{* *}$ & $-1.5149^{* *}$ \\
\hline $\mathrm{SCC} \geq \mathrm{Xcum} 8$ & $-2.6190^{* *}$ & $-2.1155^{* *}$ & $-1.7758^{* *}$ \\
\hline $\mathrm{SCC} \geq \mathrm{Xcum} 9$ & $-3.2597^{* *}$ & $-2.5678^{* *}$ & $-2.1286^{* *}$ \\
\hline $\mathrm{SCC} \geq \mathrm{Xcum} 10$ & $-4.5676^{* *}$ & $-3.8579^{* *}$ & $-3.2985^{* *}$ \\
\hline Lactation $2+$ & $1.2223^{* *}$ & $1.1594^{* *}$ & $1.0930^{* *}$ \\
\hline Cows 100-499 & 0.1033 & -0.1712 & -0.1646 \\
\hline Cows 500-999 & $2.3689^{*}$ & $2.0630 \dagger$ & $2.1464 \dagger$ \\
\hline Cows $1,000+$ & $4.9529^{* *}$ & $4.6219^{* *}$ & $4.6041^{* *}$ \\
\hline $\mathrm{R}^{2}$ & 0.3370 & 0.3276 & 0.3241 \\
\hline
\end{tabular}

${ }^{1} 5,415,940$ cow observations; the base scenario is a Holstein cow on test day (TD) 1 in her first lactation milked $3 \times$ a day in a herd with less than 99 cows during the spring. MFQ $=$ milking frequency; DIMSQ $=$ DIM on test day squared; Xcumt $=$ cumulative number of test days, t, with $\mathrm{SCC} \geq \mathrm{X}(\mathrm{X}=100,200$, or 300$)$.

$\dagger P<0.1,{ }^{*} P<0.05,{ }^{* *} P<0.01$. 
dium and high group. Somatic cell count had a negative and significant effect that was of the same absolute value but a smaller relative value given the much higher milk output. No significant differences in milk production across herd size categories were observed for highproducing cows.

\section{Results with SCC Thresholds}

Hand et al. (2012) suggested that SCC $\geq 100,000$ cells $/ \mathrm{mL}$ was a good predictor of possible mastitis and associated milk yield loss due to mastitis. We studied the effect of mastitis in this analysis by using SCC above $100,000,200,000$, or 300,000 cells/mL as a proxy. A binary variable, SCC $\geq \mathrm{Xcumt}$, was generated for each SCC threshold, X, and cumulative number of test days, t. This binary variable accounts for the number of consecutive test days above the specified SCC threshold. For example, SCC $\geq 100$ cum5, was set equal to 1 for all cows that had 5 consecutive months of a SCC $\geq 100,000$ cells $/ \mathrm{mL}$, all others were 0 . Table 3 presents the distribution of observations across the SCC categories. The categories of SCC $\geq 200,000$ and SCC $\geq 300,000$ are subsets of the first column (SCC $\geq 100,000$ ), so estimates should not be compared across columns. Over $23 \%$ of all observations had at least 1 mo with SCC $\geq 100,000$ cells $/ \mathrm{mL}$, whereas only $16 \%$ of the observations had 1 mo SCC $\geq 300,000$. Table 4 displays estimated fixed effects regression results including the consecutive cumulative SCC variable described previously. This analysis was completed on all cows for an overall average. For the variables in common with Table 2 , the coefficients follow an almost identical pattern.

Results show that as the number of TD with consecutive SCC scores above the threshold, the decrease in milk production increased (Table 4 ). Note that the TD effect of each successive SCC above a threshold had a larger effect on milk production. That is, the daily losses from each month exceeding a given threshold were larger than the previous month. The average marginal effect of exceeding 100,000 cells/mL was larger than exceeding the 200,000 or 300,000 cells $/ \mathrm{mL}$ threshold for each cumulative and consecutive TD. These results suggest that including cumulative SCC threshold variables provides additional information on lactation milk yields and supports Hand et al. (2012), who recommended for a threshold of 100,000 cells/mL as a proxy for mastitis rather than a higher threshold.

\section{Valuing Milk Losses}

The monetary cost of cumulative test days of increased SCC were quantified using regression coefficients estimated with the fixed effects regression shown in Table 4. Multiplying the estimated coefficients by the average US milk price over the study period, $\$ 0.45 / \mathrm{kg}$ $(\$ 20.54 / \mathrm{cwt})$, results in a unique cost for each potential characteristic or explanatory variable in the analysis (Table 5; USDA-NASS, 2016). Perhaps the most important aspect of Table 5 is that it puts the daily milk losses related to SCC thresholds in a monetary context. A negative value indicates a monetary loss and a positive value a gain for that characteristic. The largest losses occur from the cumulative months above SCC thresholds, with daily losses for SCC >100,000 cells/ $\mathrm{mL}$ valued at $\$ 1.20 /$ cow per day in the first month and increasing to $\$ 2.06 /$ cow per day in mo 10 .

We provide an example scenario to demonstrate how results from our study can be used in practice, as not all of the estimated coefficients will be used to calculate the monetary loss of any given individual cow. Consider a Holstein cow in her first lactation that calved

Table 5. Average daily monetary effects (\$/cow per day) of cow and operation characteristics on milk yield ${ }^{1,2}$

\begin{tabular}{|c|c|c|c|}
\hline \multirow[b]{2}{*}{ Characteristic } & \multicolumn{3}{|c|}{ Test-day SCC threshold } \\
\hline & $\geq 100,000$ & $\geq 200,000$ & $\geq 300,000$ \\
\hline Constant & 16.02 & 15.91 & 15.86 \\
\hline Jersey & -4.50 & -4.45 & -4.45 \\
\hline Crossbred & -2.69 & -2.91 & -2.93 \\
\hline MFQ & -1.00 & -1.02 & -1.02 \\
\hline DIM & 0.01 & 0.01 & 0.01 \\
\hline DIMSQ & $-3.11 \mathrm{E}-05$ & $-3.38 \mathrm{E}-05$ & $-3.49 \mathrm{E}-05$ \\
\hline Summer & -0.36 & -0.36 & -0.37 \\
\hline Fall & -0.72 & -0.72 & -0.72 \\
\hline Winter & -0.26 & -0.25 & -0.25 \\
\hline TD2 & 2.02 & 2.13 & 2.16 \\
\hline TD3 & 1.89 & 1.99 & 2.01 \\
\hline TD4 & 1.47 & 1.55 & 1.56 \\
\hline TD5 & 1.02 & 1.08 & 1.08 \\
\hline TD6 & 0.60 & 0.64 & 0.64 \\
\hline TD7 & 0.22 & 0.23 & 0.22 \\
\hline TD8 & -0.14 & -0.18 & -0.20 \\
\hline TD9 & -0.55 & -0.67 & -0.70 \\
\hline TD10 & -1.08 & -1.33 & -1.42 \\
\hline $\mathrm{SCC}$ & $-4.09 \mathrm{E}-04$ & $-4.19 \mathrm{E}-04$ & $-4.49 \mathrm{E}-04$ \\
\hline $\mathrm{SCC} \geq \mathrm{Xcum} 1$ & -1.20 & -0.88 & -0.71 \\
\hline $\mathrm{SCC} \geq \mathrm{Xcum} 2$ & -0.55 & -0.27 & -0.11 \\
\hline $\mathrm{SCC} \geq \mathrm{Xcum} 3$ & -0.56 & -0.33 & -0.18 \\
\hline $\mathrm{SCC} \geq \mathrm{Xcum} 4$ & -0.66 & -0.46 & -0.32 \\
\hline $\mathrm{SCC} \geq \mathrm{Xcum} 5$ & -0.75 & -0.60 & -0.47 \\
\hline $\mathrm{SCC} \geq \mathrm{Xcum} 6$ & -0.85 & -0.70 & -0.58 \\
\hline $\mathrm{SCC} \geq \mathrm{Xcum} 7$ & -0.98 & -0.81 & -0.68 \\
\hline $\mathrm{SCC} \geq \mathrm{Xcum} 8$ & -1.18 & -0.95 & -0.80 \\
\hline $\mathrm{SCC} \geq \mathrm{Xcum} 9$ & -1.47 & -1.16 & -0.96 \\
\hline $\mathrm{SCC} \geq \mathrm{Xcum} 10$ & -2.06 & -1.74 & -1.48 \\
\hline Lactation $2+$ & 0.55 & 0.52 & 0.49 \\
\hline Cows 100-499 & 0.05 & -0.08 & -0.07 \\
\hline Cows 500-999 & 1.07 & 0.93 & 0.97 \\
\hline Cows $1,000+$ & 2.23 & 2.08 & 2.07 \\
\hline
\end{tabular}

${ }^{1}$ Multiply the estimated coefficients in Table 4 by $\$ 0.45$ to generate these estimates.

${ }^{2} \mathrm{MFQ}=$ milking frequency; DIMSQ $=$ DIM on test day squared; TD $=$ test day; Xcumt $=$ cumulative number of test days, $\mathrm{t}$, with $\mathrm{SCC} \geq$ $\mathrm{X}(\mathrm{X}=100,200$, or 300$)$. 


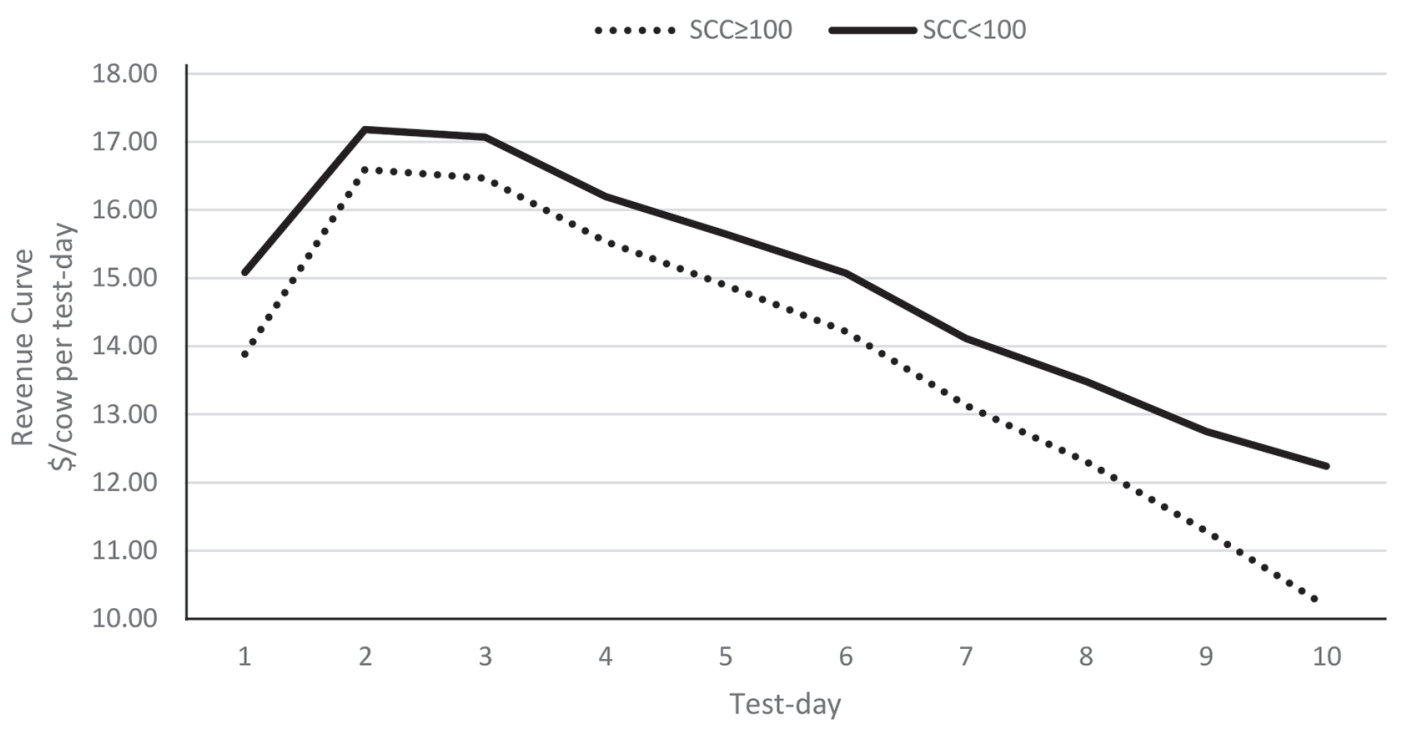

Figure 1. Example revenue curve for a Holstein cow in her first lactation that calved in the spring, was milked $3 \times$ a day, and had an average SCC of 197,000 cells/mL compared to an identical cow that had an average SCC $<100,000$ cells $/ \mathrm{mL}$.

in the spring and is 90 DIM. She has an average SCC of 197,000 cells $/ \mathrm{mL}$ and is in the smallest herd size category milked twice daily. The cow just completed her third test day (TD3) and for each of those 3 mo she had a SCC $\geq 100,000$ cells $/ \mathrm{mL}$. Using this information and the monetary results reported in Table 5 for SCC $\geq 100,000$ cells $/ \mathrm{mL}$, we are able to determine that this set of characteristics was equivalent to revenue of $\$ 16.47 /$ cow per day $[16.02-1.00+(0.005 \times 90)-$ $\left(0.0000311 \times 90^{2}\right)+1.89-(0.000409 \times 197)-0.56$ $=16.47$. Compare this value to the revenue potential with SCC $<100,000$ cells $/ \mathrm{mL}$ over these $3 \mathrm{mo}$, which was $\$ 17.03 /$ cow per day $(16.47+0.56=17.03)$. This particular cow is losing an average of $\$ 0.56 /$ cow per day in revenue on TD3 due to the cumulative number of days with increased SCC and her specified characteristics. This same process can be completed across SCC threshold and various explanatory variables. The monetary estimates in Table 5 reveal the individual characteristics that have a larger effect compared with others, which can be used to assist management decisions. For example, whereas DIM and DIMSQ were statistically significant in Table 2, their monetary effect was less than a penny; herd size can increase revenue potential to around $\$ 2$ if the cow was in the largest herd size $(1,000+$ cows $)$.

Figure 1 presents the potential milk revenue effects for this example cow over a lactation. The solid line assumes a SCC $<100,000$ cells $/ \mathrm{mL}$ across her lactation whereas the dotted line shows the monetary effects of $t$ consecutive months of $\mathrm{SCC} \geq 100,000$ cells $/ \mathrm{mL}$. By mo 10 of her lactation, this cow was losing approximately $\$ 2.06 /$ cow per day due to 10 consecutive months of
SCC $\geq 100,000$ cells $/ \mathrm{mL}$. The same interpretation can be followed for a cow with SCC $\geq 200,000$ or 300,000 cells/mL in Table 5 . The losses presented in Figure 1 demonstrate the incremental cost of consecutive TD greater than the SCC threshold. At the margin, consecutive TD above $\mathrm{SCC} \geq 100,000$ cells $/ \mathrm{mL}$ results in the largest increasing daily losses in milk revenue emphasizing more targeted management efforts to maintain SCC $<100,000$ provide the greatest revenue potential.

Using SCC thresholds as a proxy for mastitis and cumulative months above the threshold as a proxy for chronic mastitis at cow level, we were able to use these values to assist in targeting mastitis-control measures. Larger losses might motivate control efforts across the cow's lactation. In particular, the building effect of the cumulative TD above the threshold SCC levels might be of use in treatment and culling decisions. Reducing or eliminating these losses must be compared with the treatment costs and efforts, but a first step is understanding magnitude and factors associated with milk yield losses.

\section{CONCLUSIONS}

This analysis focused on understanding how increased SCC affects milk production. Using a large DHI data set from October 2013 through December 2014, the effects of cow and herd factors on milk yield were examined. The results demonstrate the increasing effect of exceeding SCC thresholds on milk loss. Importantly, cumulative TD above 100,000 SCC resulted in increasing daily milk yield losses across the cow's lactation. Further, we valued these milk yield losses by assigning 
a monetary value for each estimated coefficient in our regression analysis. Results demonstrated the increasing costs of consecutive months with SCC above a specified threshold. The largest losses were found to occur from increased cumulative test days with a SCC $\geq 100,000$ cells $/ \mathrm{mL}$, with daily losses of $\$ 1.20 /$ cow per day in the first month to $\$ 2.06 /$ cow per day in mo 10. Mastitis management decisions center around the tradeoffs between mastitis cost-control measures and the foregone revenue associated with milk yield. This analysis provides farm managers with the ability to analyze these tradeoffs and highlights the importance of mastitis control and early detection.

\section{ACKNOWLEDGMENTS}

The authors thank the USDA-Animal and Plant Health Inspection Service for funding the cooperative agreement for this project as well as Jacqueline Holland (Colorado State University) for assistance with collecting and formatting data provided by AgriTech Analytics (Visalia, CA), AgSource Cooperative Services (Verona, WI), and Dairy Records Management Systems (DRMS; Raleigh, NC).

\section{REFERENCES}

Bar, D., Y. T. Grohn, G. Bennett, R. N. Gonzalez, J. A. Hertl, H. F. Schulte, L. W. Tauer, F. L. Welcome, and Y. H. Schukken. 2007. Effect of repeated episodes of clinical mastitis on milk yield in dairy cows. J. Dairy Sci. 90:4643-4653.

Bar, D., L. W. Tauer, G. Bennett, R. N. Gonzalez, J. A. Hertl, Y. H. Schukken, H. F. Schulte, F. L. Welcome, and Y. T. Grohn. 2008. The cost of generic clinical mastitis in dairy cows as estimated by using dynamic programming. J. Dairy Sci. 91:2205-2214.

Barkema, H. W., Y. H. Schukken, T. J. G. M. Lam, M. L. Beiboer, G. Benedictus, and A. Brand. 1999. Management practices associated with incidence rate of clinical mastitis. J. Dairy Sci. 82:1643-1654.

Bartlett, P. C., G. Y. Miller, C. R. Andersen, and J. H. Kirk. 1990 Milk production and somatic cell count in Michigan dairy herds. J. Dairy Sci. 73:2794-2800.

DeGraves, F. J., and J. Fetrow. 1993. Economics of mastitis and mastitis control. Vet. Clin. North Am. Food Anim. Pract. 9:421-434.

Durr, J. W., R. I. Cue, H. G. Monardes, J. Moro-Mendez, and K. M. Wade. 2008. Milk losses associated with somatic cell counts per breed, parity, and stage of lactation in Canadian dairy cattle. Livest. Sci. 117:225-232.

Erdman, R. A., and M. Varner. 1995. Fixed yield responses to increased milking frequency. J. Dairy Sci. 78:1199-1203.

Geary, U., N. Lopez-Villalobos, N. Begley, F. McCoy, B. O'Brien, L. O'Grady, and L. Shalloo. 2012. Estimating the effect of mastitis on the profitability of Irish dairy farms. J. Dairy Sci. 95:3662-3673.
Hand, K. J., A. Godkin, and D. F. Kelton. 2012. Milk production and somatic cell counts: A cow-level analysis. J. Dairy Sci. 95:13581362.

Hortet, P., F. Beaudeau, H. Seegers, and C. Fourichon. 1999. Reduction in milk yield associated with somatic cell counts up to 600000 cells/ml in French Holstein cows without clinical mastitis. Livest. Prod. Sci. 61:33-42.

Hortet, P., and H. Seegers. 1998. Loss in milk yield and related composition changes resulting from clinical mastitis in dairy cows. Prev. Vet. Med. 37:1-20.

Houben, E. H. P., A. A. Dijkhuizen, J. A. M. Van Arendonk, and R. B. M. Huirne. 1993. Short- and long-term production losses and repeatability of clinical mastitis in dairy cattle. J. Dairy Sci. 76:2561-2578.

Jones, G. M., R. E. Pearson, G. A. Clabaugh, and C. W. Heald. 1984. Relationship between somatic cell counts and milk production. J. Dairy Sci. 67:1823-1831.

Kadri, N. K., B. Guldbrandtsen, M. Lund, and S. Goutam. 2015. Genetic dissection of milk yield traits and mastitis resistance quantitative trait loci on chromosome 20 in dairy cattle. J. Dairy Sci. 98:9015-9025.

Lescourret, F., and J. B. Coulon. 1994. Modeling the impact of mastitis on milk production by dairy cows. J. Dairy Sci. 77:2289-2301.

Miller, R. H., H. D. Norman, G. R. Wiggans, and J. R. Wright. 2004 Relationship of test-day somatic cell score with test-day lactation milk yields. J. Dairy Sci. 87:2299-2306.

Norman, H. D., L. M. Walton, and J. Durr. 2016. Somatic cell counts of milk from Dairy Herd Improvement herds during 2016. CDCB Research Report SCC18: 2-17.

Ostergaard, S., and Y. T. Grohn. 1999. Effects of diseases on test day milk yield and body weight of dairy cows from Danish research herds. J. Dairy Sci. 82:1188-1201.

Prendiville, R., K. M. Pierce, and F. Buckley. 2009. An evaluation of production efficiencies among lactation Holstein-Friesian, Jersey, and Jersey x Holstein-Friesian cows at pasture. J. Dairy Sci. 92:6176-6185.

Rollin, E., K. C. Dhuyvetter, and M. W. Overton. 2015. The cost of clinical mastitis in the first 30 days of lactation: An economic modeling tool. Prev. Vet. Med. 122:257-264.

Seegers, H., C. Fourichon, and F. Beaudeau. 2003. Production effects related to mastitis and mastitis economics in dairy cattle. Vet. Res. 34:475-491.

Smith, J. W., L. O. Ely, and A. M. Chapa. 2000. Effect of region, herd size, and milk production on reasons cows leave the herd. J. Dairy Sci. 83:2980-2987.

StataCorp. 2015. Stata Statistical Software: Realease 14. StataCorp LP, College Station, TX.

Swinkels, J. M., H. Hogeveen, and R. N. Zadoks. 2005. A partial budget model to estimate economic benefits of lactational treatment of subclinical staphylococcus aureus mastitis. J. Dairy Sci. 88:4273-4287.

USDA-NAHMS. 2016. Dairy 2014: Milk quality, milking procedures, and mastitis on U.S. Dairies, 2014. Report 2. Accessed Feb. 16, 2017. https://www.aphis.usda.gov/animal_health/nahms/dairy/ downloads/dairy14/Dairy14_dr_Mastitis.pdf.

USDA-NASS. 2016. Agricultural Prices. January 2016. Accessed Feb. 16, 2017. http://usda.mannlib.cornell.edu/usda/nass/AgriPric// 2010s/2016/AgriPric-01-29-2016.pdf.

Wooldridge, J. M. 2002. Econometric analysis of cross section and panel data. MIT Press, Cambridge, MA. 